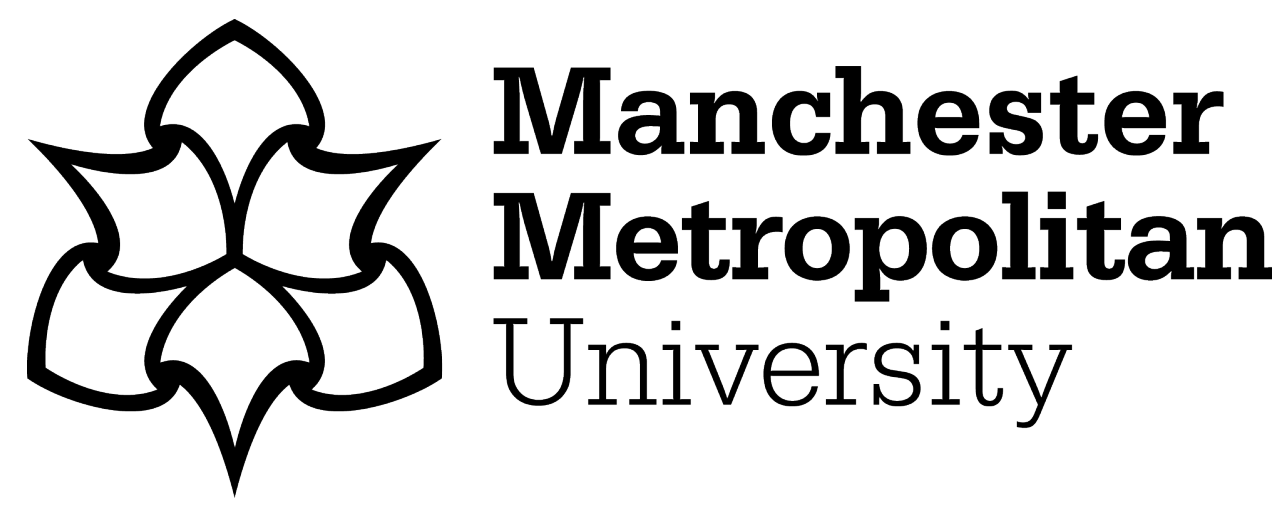

Dewick, Paul, Maytorena-Sanchez, Eunice and Winch, Graham (2019) Regulation and Regenerative eco-innovation: the case of extracted materials in the UK. Ecological Economics, 160. pp. 38-51. ISSN 0921-8009

Downloaded from: https://e-space.mmu.ac.uk/622502/

Version: Accepted Version

Publisher: Elsevier

DOI: https://doi.org/10.1016/j.ecolecon.2019.01.034

Usage rights: Creative Commons: Attribution-Noncommercial-No Derivative Works 4.0

Please cite the published version 


\title{
Regulation and regenerative eco-innovation: the case of extracted materials in the UK
}

By Paul Dewick ${ }^{a, b}$, Eunice Maytorena-Sanchez ${ }^{c}$ and Graham Winch ${ }^{c}$

a Department of Strategy, Enterprise and Sustainability, Manchester Metropolitan University

${ }^{\mathrm{b}}$ Manchester Institute of Innovation Research, The University of Manchester

'Alliance Manchester Business School, The University of Manchester

0044161306 3435, p.dewick@mmu.ac.uk or paul.dewick@manchester.ac.uk

Forthcoming in Ecological Economics, 2019

\begin{abstract}
Regenerative eco-innovation, demanding radical and architectural change to restore, renew and revitalise the natural system, is arguably the most important type of eco-innovation to address the pressing challenges of sustainable development. The aim of this paper is to explore the role of the regulatory framework and wider contextual conditions in facilitating or hindering regenerative ecoinnovations. This is especially relevant for the built environment, a sector that is highly regulated and where rates of innovation are typically slow. We combined a review of relevant archival material with an interview programme involving key stakeholders from the UK's built environment sector. We contribute to the literature by extending and elaborating our understanding of regenerative ecoinnovation in two ways. First, we extend the literature on regulation and eco-innovation by exploring what constitutes high quality regulation in the context of regenerative development. Second, we elaborate on how regenerative eco-innovations are facilitated or hindered by wider contextual conditions. Our paper also has practical utility. More understanding of how effective regulation can support regenerative eco-innovations, and of how the wider contextual conditions facilitate or hinder regenerative eco-innovations, allows industry and government to respond better to the urgent global challenge of closing material cycles.
\end{abstract}

\section{Key words}

Regenerative eco-innovation, regulation, roots of eco-innovation, built environment, extracted materials Highlights

- Explores the influence of regulation and wider contextual conditions on regenerative eco-innovation

- Focuses on a case study of extracted materials in the UK built environment sector

- Extends and elaborates our understanding of regenerative eco-innovation in two ways:

- 1) what constitutes high quality regulation in the context of regenerative development

- 2) how the regulatory roots of regenerative eco-innovation are affected by wider contextual conditions

\section{Acknowledgements}

The authors acknowledge the support of the Alliance Manchester Business School Research Support Fund and the contribution of Richard Ferris to a previous scoping study.

\section{Regulation and regenerative eco-innovation: the case of extracted materials in the UK}




\section{Introduction}

To respond to the United Nation's Sustainable Development Goals for 2030 (UN, 2015), one target for policy makers is to stimulate eco-innovation: new ideas (products, processes, organisational approaches, new entrepreneurial ventures) that contribute to a reduction of environmental or social burdens, or to specified sustainability targets. Regulation offers one instrument for policy makers. The relationship between regulation and eco-innovation has been studied extensively over the last three decades and there is much evidence that regulation can trigger eco-innovation (Demirel and Kesidou, 2011; Horbach et al., 2012; Hojnik and Ruzzier, 2016; Horbach, 2016; Penasco et al. 2016, Ramanathan et al. 2016; Castellacci et al. 2017; Cai and Li, 2018; You et al., 2019). Other lines of enquiry have sought to establish what constitutes 'effective' regulation. The consensus is that stringent, flexible and enforceable regulation is best (Huber 2008, Mickwitz et al., 2008; Kesidou and Demirel, 2012; Horbach et al., 2012; Auld et al., 2014, Dong et al., 2014; Hojnik and Ruzzier, 2016; Horbach, 2016; Popp et al., 2011). Some authors, such as Ribeiro and Kruglianskas (2015), have gone further, expanding on the characteristics of high quality regulation. But designing a high quality environmental regulatory framework that leads to lasting intended consequences remains a complex task for policy makers. In an extensive evaluation of the effects of policies promoting low carbon technologies, Auld et al. (2014) evidence the high (55\%) proportion of regulation evaluated ex-post that leads to negative outcomes (when outcomes fall short of expectations) or mixed outcomes (when regulation had aspects that went well but also things that went wrong).

Regenerative eco-innovation (Hofstra and Huisingh, 2014) is arguably the most important type of ecoinnovation to address the pressing challenges of sustainable development. Regenerative ecoinnovations go beyond those innovations that meet minimum requirements or maximise eco-efficiency toward those which "restore, renew [and] revitalise" natural systems, allowing humans to work in harmony with, instead of abusing and exploiting, the eco-system (ibid. p.464). Regenerative ecoinnovation is considered to be the most challenging type of eco-innovation to develop and diffuse; hence, the type most in need of regulatory support. While previous studies have explored the relationship between regulation and other proximate drivers in stimulating the development and diffusion of product, process and organisational eco-innovations, to our knowledge there are no studies that have focused on the wider contextual conditions facilitating or hindering regenerative ecoinnovations. Indeed, Hofstra and Huisingh (2014) call for more empirical work on regenerative ecoinnovation to support theory building, and Hojnik and Ruzzier (2016) call for more work into the distal drivers of eco-innovations.

To address this knowledge gap, the aim of our research is to explore the role of the regulatory framework and wider contextual conditions in facilitating or hindering regenerative eco-innovations. We employed a case study strategy, selecting a case with a close theoretical and empirical fit. Regenerative development resonates with the production and consumption of the built environment, where production is typically destructive for the natural environment and where product lifetimes are measured in decades or centuries. The built environment sector is the largest consumer of natural resources and generates 
between 25 and $30 \%$ of all waste in the EU 1 . The sector is also highly regulated and rates of innovation, including eco-innovation, are typically slow (Nam and Tatum, 1988; Gann, 1994; Dewick and Miozzo, 2002a, 2002b; Miozzo and Dewick, 2004). Our case focused on construction and demolition in the UK and, in particular, eco-innovative uses of extracted materials. A surge of large construction projects has brought into the foreground innovative uses of extracted material to deliver a net positive environmental and human impact. To explore the role of the regulatory framework and wider contextual conditions in facilitating or hindering regenerative eco-innovations, we combined a review of the relevant archival material with an interview programme involving key sector stakeholders including regulators, contractors, consultants, clients and trade associations. We interviewed 30 individuals between May and September 2017.

In this paper, we contribute to the literature by extending and elaborating our understanding of regenerative eco-innovation. First, we extend the literature on regulation and eco-innovation by exploring what constitutes high quality regulation in the context of regenerative development. Second, we elaborate on how regenerative eco-innovations are facilitated or hindered by wider contextual conditions. In addition to this theoretical contribution, our paper also has practical utility. More understanding of how effective regulation can support regenerative eco-innovations, and of how the wider contextual conditions facilitate or hinder regenerative eco-innovations, allows industry and government to respond better to the urgent global challenge of closing material cycles and avoiding sending waste to landfill.

\section{Literature review}

There is an extensive literature on regulation and innovation. In an early contribution, Rothwell (1992) explained how policy makers came under increasing pressure from the late 1960s onwards for more stringent environmental regulation to minimise the negative effects on firms without compromising the protection of the environment. Rothwell did not think the negative impact of regulation on industrial innovation was inevitable; rather that it depended on the nature of the regulation and behaviour of the regulatory agencies. He compared different types of regulation, contrasting direct regulation (elsewhere referred to as 'command and control' regulation) with economic incentives/disincentives (often referred to as market based measures); performance standards with specification standards; and process change (also referred to as 'cleaner production') with 'end-of-pipe' clean-up. He argued in favour of market based, performance based, process change regulation, that was flexible (with respect to time) and anticipatory (to encourage 'best practicable' process change). In his view, the regulatory process should be autonomous (i.e. separate from industry), well informed, context dependent, participatory, clear (i.e. unambiguous) and harmonised internationally. Over 20 years later, Ribeiro and Kruglianskas (2015) came to similar conclusions. Following a review of international regulatory initiatives mainly from the 1990s, Ribeiro and Kruglianskas concluded that there was a consensus about what constituted 'high quality' environmental regulation: participatory, decentralized,

\footnotetext{
${ }^{1}$ http://ec.europa.eu/environment/waste/construction demolition.htm, last accessed November 2018
} 
flexible, simple and clear, preventive, inducer of innovation, multi-instrumental, rigorous on enforcement, performance-based, planned and gradual, supported by adequate resources, measured and communicated, and reflexive. Between the studies of Rothwell (1992) and Ribeiro and Kruglianskas (2015), many other articles had come to the same (but less elaborate) conclusion that the most effective type of regulation is stringent, flexible and enforceable (e.g. Huber, 2008; Mickwitz et al., 2008; Popp et al., 2011; Kesidou and Demirel, 2012; Horbach et al., 2012; Auld et al., 2014; Dong et al., 2014, amongst others).

Eco-innovation is a plural concept associated with new ideas (products, processes, organisational approaches, new intra/entrepreneurial ventures) that contribute to a reduction of environmental or social burdens, or to specified sustainability targets. The relationship between regulation and different types of eco-innovation has been explored many times in (mainly) empirical studies of the determinants of eco-innovation. Recent studies illustrate the variety of research, from studying the determinants of eco-innovations across regions, e.g. in eastern European countries (Horbach, 2016), through studies of eco-innovation within national boundaries, e.g. in China (Cai and Li, 2018; You et al., 2018) and Nigeria (Sanni, 2018), to more specific sectoral studies, e.g. food and beverage manufacturing in Spain (Triguero et al., 2018) and ceramic tile manufacture in Brazil (de Souza et al., 2018). Early empirical work showed a significant relationship between regulation and eco-innovation (Green et al., 1994; Kemp, 1997; Rennings, 2000). Rennings (2000) attributed this to what he called the 'regulatory push/pull' effect, compensating for a weak technology push and market pull for ecoinnovation. Later studies expanded on the role of regulation in driving eco-innovation. For example, Popp (2006) and Penasco et al. (2016) showed that whilst national regulation is a strong driver of ecoinnovation, the effect of international regulation is more modest; Mickwitz et al., (2008), Khanna et al. (2009) and Horbach et al. (2012) evidenced that both present and future regulation stimulate ecoinnovation; and Veugelers (2012) showed that combining regulation with other policy instruments better stimulates eco-innovation. In a meta-analysis of 155 studies exploring the determinants of ecoinnovation published after 2000, Hojnik and Ruzzier (2016) concluded that regulations constitute the "most commonly and frequently reported trigger of eco-innovation" (p.38). Whilst most previous studies focus on the determinants of product or process eco-innovations, both of which are shown to be driven by regulation, there has also been much interest in the literature on environmental technology. Rothwell (1992) differentiated between end-of-pipe technology and (integrated) cleaner production technology. Recent literature suggests that regulation has a relatively greater effect on endof-pipe technologies such as those reducing air emissions, noise, soil, hazardous substances; a more modest effect on cleaner production technologies (Horbach et al., 2012; Castellacci and Lie, 2017). Organisational eco-innovations include both inter- and intra-organisational activities that advance strategies to reduce environmental impacts (Dewick and Aylen, 2014). Inter-organisational ecoinnovations include collaborative supply chain arrangements, enabling a company to work with upstream suppliers and downstream customers in ways that reduce environmental or social burdens relative to existing approaches. Intra-organisational eco-innovations include sustainable/ethical business models, environmental management practices, environmental reporting and other internal 
operations that help firms identify and then act to reduce environmental impacts. Previous research indicates a positive relationship between organisational eco-innovations and product and process ecoinnovations (Rennings et al., 2006; Wagner, 2008). More recent research indicates that organisational eco-innovations can be also triggered by regulation (Triguero et al., 2013; Hojnik and Ruzzier, 2016).

In innovation studies, it is common to distinguish between incremental and radical innovation, and between component and architectural innovation. In the case of eco-innovations, the incremental and radical nature refers to the impact on environmental performance: incremental when innovation leads to minor improvements in the environmental performance of products, processes, technologies and organisational approaches; radical when innovation involves major improvements often replacing existing products, processes, technologies and organisational approaches (Wagner and Llerena, 2011). The extent to which eco-innovations change the existing system is a related idea, and a distinction is drawn between component and architectural eco-innovations. Component ecoinnovations refer to new modules nested within existing systems; architectural eco-innovations change the overall system design and the way the modules interact with each other (Hellstrom, 2007). Environmental technology provides a good example of the different types. End-of-pipe technologies that treat waste and pollution tend to be incremental, component eco-innovations that marginally improve environmental performance and leave the production process largely unchanged. Cleaner production technologies require a more fundamental change in the architecture of production processes and have a more radical effect on performance. An alternative typology of eco-innovation has been proposed by Hofstra and Huisingh (2014) who separate (1) 'exploitative or degenerative' eco-innovations, designed to meet minimum requirements, (2) 'restorative' eco-innovations, which maximise eco-efficiency, (3) 'cyclical' eco-innovations, which consider explicitly the connection between humans and their social and cultural structures as integral constituents of eco-systems, and (4) 'regenerative' eco-innovations in which the vitality of the eco-system is used to create added value for humans and nature. Regenerative eco-innovations are at the top of this hierarchy and can be considered the most radical, requiring fundamental architectural change. Hofstra and Huisingh (2014, p.464) position regenerative eco-innovations as the most desirable as they can "restore, renew [and] revitalise" natural systems, allowing humans to work in harmony with, instead of abusing and exploiting, the eco-system. Regenerative eco-innovations are consistent with new approaches that comprehensively value services provided by the natural environment, such as the natural capital framework of Helm (2015), and are an important part of the transformative agenda to meet the UN's Sustainable Development Goals for 2030 (UN, 2015).

Whilst we know much about regulation and eco-innovation, and about what constitutes high quality regulation, the relationship between regulation and regenerative eco-innovation has been neglected in the literature. Our study is a first attempt to close that gap. Given the significance of regulation as a determinant of eco-innovation and the importance of regenerative eco-innovation for sustainable development, it is necessary to explore the relationship between regulation and regenerative ecoinnovations. It is also important to explore the wider contextual conditions that facilitate or hinder 
regenerative eco-innovation. Whilst the literature is clear that eco-innovation has regulatory roots, there are other antecedents of eco-innovation. To make sense of these antecedents, researchers have employed different theoretical frameworks. Rennings (2000) combined regulatory push with technology push and market pull in his framework to explain the drivers of eco-innovation. Later authors reconfigured and expanded this framework, arguing that eco-innovations were determined by demand side (market pull; social awareness), supply side (firm capabilities; appropriation) and institutional and political influences (structure of the institutional field; policy) (Horbach, 2008; Horbach et al., 2012; Triguero et al., 2013). Cecere et al. (2014) evidenced three conditions that hinder the adoption of eco-innovations. First, the costs related to the adoption of eco-innovations, which includes acquiring knowledge, developing competences and investing in infrastructure. Second, the complexity of the knowledge base underpinning current ways of doing things, and the interdependencies and complementarities between different parts of the technological system. Third, the role of stakeholders, including those internal to the organisation (where it can be difficult for firms to coordinate actions across functions or departments) and external to the organisation (where formal and informal institutions can constrain behaviours and where social actors may not share common meanings or standard behaviours). Hojnik and Ruzzier (2016) reviewed other theoretical frameworks used to study the determinants of eco-innovation, including institutional theory, neo-institutional theory and stakeholder theory, but argued that if you look beyond the theoretical lens, the antecedents are essentially the same: regulation, market demand, competitors, expected benefits, and characteristics of the organisation (firm size/age, capabilities and resources). Where Hojnik and Ruzzier (2016) are critical of the literature is in its focus on the proximate determinants of eco-innovation. They call for more work into the distal factors. Cecere et al. (2014) based their framework on notions of lock-in and path dependence, concepts which are central to innovation studies' explanation of sustainable change at a systems level. Many studies (e.g. Coenan and Diaz Lopez, 2011; Vergragt et al. 2014; Dewick and Foster, 2018) note the inter-dependent, co-evolving pathways for innovation and the central role of actors (e.g. organisations, technology), networks (e.g. physical infrastructures, knowledge networks) and institutions (e.g. formal institutions such as government policies, regulation, standards; informal institutions such as practices, life styles and behaviours) in shaping the direction and pace of change. Exploring these contextual conditions in a rich case study potentially contributes to a better understanding of the distal factors that facilitate and hinder regenerative eco-innovations.

Our review reveals a gap concerning the relationship between regulation and regenerative ecoinnovation. More generally, Hoftstra and Huisingh's (2014) concept of regenerative eco-innovation requires empirical work to support theory building. Our review also identifies a large literature on the proximate determinants of eco-innovation but a gap concerning the distal contextual conditions that facilitate and hinder eco-innovation (Hojnik and Ruzzier, 2016). The aim of our paper is to explore the role of the regulatory framework and wider contextual conditions in facilitating or hindering regenerative eco-innovation. In the next section, we explain why we chose a case study of the UK built environment sector focusing on eco-innovative uses of extracted materials. 


\section{Method}

\subsection{Research site}

We selected an interesting site that potentially offered insights into the relationship between regulation and regenerative eco-innovations. We chose the built environment sector and, more specifically, construction and demolition and the innovative uses of extracted materials as a close theoretical and empirical fit. Hofstra and Huisingh (2014, p.464) describe regenerative eco-innovations as those "designed to work with nature...[to]... restore, renew, revitalize and ensure rebirth to their own sources of energy and materials by taking into account future needs, wants and desires of society and nature and by doing so within the natural systems of nature". The concept of regenerative development resonates with the production and consumption of the built environment, a sector whose production is typically destructive for the natural environment and whose consumption must be considered in terms of decades (and centuries). Du Plessis (2012, p.15) notes how the concept of 'regenerative design and development' leads built environment stakeholders toward strategies that increase natural and social capital; not only preserving and protecting, but restoring a lost plenitude (van der Ryn and Cowen 2007). This requires a step change away from current 'green' strategies based on ideas of ecological modernisation to reduce resource use and environmental impacts (Cole, 2012) toward strategies that promote regenerative development "through a set of localized ecological design and engineering practices" (Du Plessis, 2012, p19). Waste management strategies are one part of regenerative development in the built environment (Geng et al., 2016; Ness and Xing, 2017). Shifting away from current incremental improvements in practices toward something more radical, consistent with regenerative development, requires technical (e.g. product/process), organisational and institutional (e.g. mindset, social norms) changes among built environment sector stakeholders (Mang and Reed, 2012; Cole, 2012).

From an empirical perspective, the peculiarities of the built environment warrant closer attention. The rate of innovation in the sector is slow, partly because of the fragmented and project based nature, and the sector is highly regulated (Nam and Tatum, 1988; Gann, 1994; Winch, 1998; Dewick and Miozzo, 2002a, 2002b, 2004). The impact of construction and demolition on the environment and society are great: the sector is the largest consumer of natural resources and generates between 25 and $30 \%$ of all waste in the $\mathrm{EU}^{2}$. Moreover, the UK provides a specific waste management context: the UK has a historic reliance on landfill disposal (Gregson et al., 2015) and recent regulatory initiatives have focused on diverting construction, demolition and extraction (CDE) waste from landfill (Adams, 2014). Bringing eco-innovation (in its various guises) to bear on alternative uses for extracted materials that add value for humans and nature is a strategy not only consistent with regenerative development but also one that echoes the UN 2030 Sustainable Development Goal 9 for quality, reliable, sustainable and resilient infrastructure to support economic development and human well-being (UN, 2015).

\footnotetext{
${ }^{2}$ http://ec.europa.eu/environment/waste/construction demolition.htm, last accessed November 2018
} 


\subsection{Research design}

We employed a case study strategy to explore the role of the regulatory framework and wider contextual conditions in facilitating or hindering regenerative eco-innovations. Case studies lend themselves to explorative research and to developing theory, especially when the subject is new (Eisenhardt, 1989). In the area of regulation and eco-innovation, it is argued that case studies are better able to capture the relevance of the local institutional context and offer more detail about a specific regulatory framework (Del Rio Gonzalez, 2009; Blind, 2012; Hojnik and Ruzzier, 2016).

To our knowledge, there has been no study of eco-innovation in the built environment that has focused on extracted materials. Whilst the wider literature on waste management has been occupied with consumer waste, studies of resource consumption and planetary degradation in the built environment have been over looked (Gregson et al., 2015; Ness and Xing, 2017). Fellner et al.'s (2017) analysis of the opportunities for recycling and re-using commodities, including aggregates, is one exception but is a high (EU) level, quantitative analysis. $\mathrm{Ng}$ et al. (2016) studied the sustainability of the extracted materials industry but focused on the design of hydraulic excavators. There has been no in-depth qualitative analysis of the eco-innovative uses of extracted materials; no consideration of the interrelated product, process and organisational eco-innovations that combine to add value for humans and nature; no studies of the relationship between regulation and regenerative eco-innovation, nor the conditions that facilitate or hinder the diffusion of regenerative eco-innovations.

\subsection{Data collection}

To address our research aim in the context of a case study of extracted materials, we collected data from two sources: archival material and interviews. The archival material consisted of relevant government publications (directives, regulations, guidance); relevant industry and professional association publications (reports and guidance) and publicly available material related to our research aim and site (national newspaper, trade news, websites of central industry actors). Our search criteria for relevant governmental publications were related to the EU Waste Directive framework and waste legislation and regulations in the UK. This helped us identify all relevant governmental regulations and guidance available to industry. We searched industry and professional association's websites for information on 'construction waste' and 'extracted/excavated material'. This initial search identified relevant news, reports and guidance. We searched in national newspapers and trade news for 'waste recovery', 'waste disposal' and 'extracted/excavated material' in construction. Prior to undertaking the interviews, this archival review allowed us to build on our understanding from the academic literature of the relationship between regulation and eco-innovation, and to gain a rich understanding of the local institutional context, impact of the regulatory framework and the roots of regenerative eco-innovation in the context of extracted materials. Following the interview programme, we further explored archival material on specific cases mentioned by interviewees. This material included publicly available information on the Northala Park, Wallasea Island and the Tarmac Aggregates Ltd. legal case. By reviewing communications from the central stakeholders (e.g. in the case of Wallasea Island: RSPB, Crossrail), industry and national media, we were able to triangulate information from the interviews. An 
aggregated list of archival material can be found in the Appendix (Appendix Table 1); references are also included in footnotes to sections 4 and 5 .

To explore further the impact of regulation and wider contextual conditions on regenerative ecoinnovations we conducted semi-structured interviews with 30 experienced stakeholders involved in the UK built environment sector who had direct involvement in construction and demolition and decision making about the reuse of extracted materials. Our interviews began with an initial set of 'elite interviews' with those persons who had "a body of knowledge or a degree of influence or a set of beliefs or opinions not otherwise held by or obtainable from, or embedded with less perceived influence or social importance than, non-elites" (Vaughan 2011:109). We supplemented those 'elite' interviews with other stakeholders following a snow balling technique. This approach allowed us to make certain a wide range of perspectives were taken into consideration. In line with a semi-structured interview approach, we developed an interview guide with a list of topics to be discussed with the interviewee (See Appendix). Following the topic guide allowed us to get close to the interviewee's perspective. In addition to broad questions, interview guides tend to include a list of probes which may be used to follow up responses and elicit greater detail from participants (Vaughan, 2011; King, 2006). We followed a topic guide probing the interviewee's reflections on the regulatory context, changes following the introduction of specific regulations, the role of key actors in driving change, and the wider factors facilitating and hindering further change. The topic guide allowed us to trace changes and explore the 'roots' of regenerative eco-innovations, focusing on the contextual conditions, the impact of 'events' and the interactions, activities and decisions of key actors that lead to the implementation of eco-innovations (Hojnik and Ruzzier, 2016). The interviews were conducted over the telephone between May and September 2017 (see Table 1 below) and lasted between 25-60 minutes. The interviews were recorded and transcribed verbatim resulting in 326 pages of transcribed material to analyse.

Table 1: List of interviewees

\begin{tabular}{|c|l|l|c|}
\hline Interviewee & Type of organisation & Job title & Interview \\
\hline 1 & Consultancy & Principal Environmental Engineer & May 2017 \\
\hline 2 & Consultancy & Director & May 2017 \\
\hline 3 & Owner/operator & Head of Environmental Sustainability & May 2017 \\
\hline 4 & Site operator & Development Director & May 2017 \\
\hline 5 & Regulator & Manager & May 2017 \\
\hline 6 & Owner/operator & Sponsor & May 2017 \\
\hline 7 & Regulator & Ground water/contaminated land specialist & May 2017 \\
\hline 8 & Regulator & Process and Policy Advisor & May 2017 \\
\hline 9 & Consultancy & Managing Director & May 2017 \\
\hline 10 & Trade association & Joint Manager & June 2017 \\
\hline 11 & Owner/operator & Environmental manager & June 2017 \\
\hline
\end{tabular}




\begin{tabular}{|c|l|l|c|}
\hline 12 & Owner/operator & Environmental manager & June 2017 \\
\hline 13 & Regulator & Environment and Business Advisor & June 2017 \\
\hline 14 & Regulator & Senior Advisor & June 2017 \\
\hline 15 & Contractor & Project Manager & June 2017 \\
\hline 16 & Contractor & Group Environmental Manager & June 2017 \\
\hline 17 & Owner/operator & Waste Manager & June 2017 \\
\hline 18 & Regulator & Advisor & June 2017 \\
\hline 19 & Contractor & Senior Environmental Manager & June 2017 \\
\hline 20 & Regulator & Senior Advisor Waste Management & June 2017 \\
\hline 21 & Contractor & Operations Director-Sustainability & June 2017 \\
\hline 22 & Contractor & Sustainability Director & June 2017 \\
\hline 23 & Contractor & Head of Environment & June 2017 \\
\hline 24 & Professional Body & Chair & July 2017 \\
\hline 25 & Contractor & Head of Strategy & July 2017 \\
\hline 26 & Regulator & Integrated Waste Manager & July 2017 \\
\hline 27 & Contractor & Director of Sustainability & July 2017 \\
\hline 28 & Consultancy & Company Director & July 2017 \\
\hline 29 & Professional Body & Data Analyst & August 2017 \\
\hline 30 & Contractor & Senior Waste and Resource Manager & Sept 2017 \\
\hline & & & \\
\hline
\end{tabular}

\subsection{Data analysis}

We inductively coded all relevant archival text material using "first order codes" and as the analysis proceeded we were able to group criteria together to develop "second order" themes (Gioia et al., 2012) about characteristics of the regulatory framework, reflections on the effectiveness of the regulation, the key actors affecting and affected by the regulatory framework, the types of ecoinnovations stimulated by regulation, and the effectiveness of the regulatory framework and the contextual conditions in facilitating and hindering regenerative eco-innovations. In this way, an initial coding framework was developed and a picture of the institutional context was built up. Interview transcripts and notes were coded drawing upon the initial coding framework, which was further developed as we contrasted the theoretical heuristics, secondary data and interview evidence.

The next section presents our findings. We structure the findings of our case around the two key aspects of our research aim, namely 1) to consider the effectiveness of the relationship between regulation and regenerative eco-innovative uses of extracted materials; and 2) to consider how the roots of regenerative eco-innovations for extracted materials are facilitated or hindered by wider contextual conditions.

\section{Findings}

\subsection{Regulation and regenerative eco-innovations in extracted materials}


Excavation wastes (known as 'spoil') include soil and stones, dredging spoil and inert sub-soils'; about $90 \%$ of extracted materials in the UK are soil and stones (Adams, 2014). The process of managing extracted materials in the UK is informed by UK wide policy on waste, which is driven by European Union (EU) waste laws. According to our interviews and review of the archival material, three pieces of legislation underpin the approach to managing waste. First, the Lisbon Treaty ${ }^{4}(2007)$ section on the environment and waste clarifies and reinforces the EU's objectives on the commitment to work towards the sustainable development of Europe. This provides the foundation for the EU's environmental policies which aim to improve, protect and preserve the quality of the environment and protect human health. Second, the EU Waste Framework Directive (WFD) $(2008)^{5}$ provides the legal framework for how waste should be treated in the EU. The Directive establishes concepts and definitions related to waste management. It was described by interviewees as an "instrumental" [interview 14], "defining piece" [interview 10] of legislation, clarifying what is and what is not a waste [interviews 10,9,19,24] and enabling a "more holistic approach to looking at a construction site; looking at the quantities [of construction, demolition and extraction materials], and looking at what can be recovered and reused" [interview 14]. In the case of extracted materials, the WFD is particularly relevant as it clarifies that extracted material, such as soil, can be classified as a by-product and not a waste. This has direct implications for industry: "It is in industry's interests to prove what they have is not a waste" [interview 10] as it avoids disposal costs [interview 10,15]. To qualify as a by-product the intended use of the extracted material must be lawful, certain and requiring only 'normal' processing (EC, 2007). ${ }^{6}$ The third key piece of legislation at the EU level is the EU Council Directive (1999) and subsequent legislation (EU Council Decision 2003/33/EC) on the landfill of waste. ${ }^{7}$ This directive is intended to reduce the detrimental effects of the landfill of waste on the environment.

At the UK level, 'controlled wastes' (defined as any household, industrial or commercial waste), fall under the jurisdiction of the UK's Environmental Protection Act (EPA) (1990) ${ }^{8}$, which defines the structure and authority for waste management and control of emissions to the environment. Authorisation and enforcement are undertaken in England and Wales by the regulator, the Environment Agency. The EPA is considered "fundamental to how the Environment Agency regulates and operates" [interview 17] imposing a "duty of care" [interview 21] on those involved. UK waste policy is influenced by the aforementioned EU level legislation and is evident in the UK Waste (England and Wales) Regulations 2011/12, and in the Environmental Permitting (England and Wales) Regulations 2010. The

\footnotetext{
${ }^{3}$ Excavation wastes are classified according to the Waste Framework Directive. Soil and stones, non-hazardous and hazardous, are coded 170504 and 17 05; dredging spoil, non-hazardous and hazardous, are coded 1705 06 and 1705 05; and inert sub-soils are coded 210101 in the Waste Framework Directive. For further details, see http://eur-lex.europa.eu/legal-content/EN/TXT/PDF/?uri=CELEX:32008L0098\&from=EN, last accessed November 2018

${ }^{4}$ https://eur-lex.europa.eu/legal-content/EN/TXT/?uri=OJ:C:2007:306:TOC, last accessed November 2018.

5 http://eur-lex.europa.eu/legal-content/EN/TXT/PDF/?uri=CELEX:32008L0098\&from=EN, last accessed November 2018

6 http://eur-lex.europa.eu/legal-content/EN/TXT/PDF/?uri=CELEX:52007DC0059\&from=EN, last accessed November 2018

7 https://eur-lex.europa.eu/LexUriServ/LexUriServ.do?uri=OJ:L:2003:011:0027:0049:EN:PDF, last accessed November 2018

${ }^{8}$ http://www.legislation.gov.uk/ukpga/1990/43/pdfs/ukpga 19900043 en.pdf, last accessed November 2018
} 
UK Waste Regulations build on the EU waste hierarchy concept presented in the EU WFD (prevent; re-use; recycle; recover; dispose). The Environmental Permitting Regulations introduce restrictions on the amount and type of waste that can be disposed of in landfills. Extracted materials that are classified as waste are handled according to the Environmental Permitting England and Wales Regulations $2010^{9}$ as either 'recovery' or 'disposal'. The classification of extracted materials as recovery or disposal is important: applying for a disposal permit requires extra work ("whole host of requirements for geological barriers... and requirements for landfill regulations" [interview 17]), adds $\operatorname{costs}^{10}$ and also requires the operator to take on long-term legacy and after-disposal care [interviews $4,9,10,11,15,17]$. Changes in Environmental Permits are judged to have had a significant impact on the sector and on the end use of extracted materials. For example, in 2010 when the UK "came out of recession and the amount of demolition and earthworks increased dramatically.... we had a new environmental [permitting] regime....[which meant that] some waste soil which otherwise would have been [recovered and] used on construction sites under waste exemptions was disposed of to landfill; we couldn't classify that material as reuse, it had to go to landfill as [a result of] a change in permitting regulations" [interview 24]. More recently, voluntary industry codes of practice have been introduced for extracted materials classified as a by-product and to be re-used "as intended" [interview 24]: CL:aire's (Contaminated Land: Applications in Real Environments) Definition of Waste: Code of Practice (DOWCOP) ${ }^{11}$ and WRAP/Environment Agency's Quality Protocol: Aggregate Code of Practice ${ }^{12}$ were mentioned by almost all interviewees. DOWCOP supports the use of extracted materials as a by-product where there are engineering uses for the extracted material on-site or at co-located sites. Under the WRAP/EA Aggregate Code of Practice inert materials such as bricks, concrete and tiles can be processed (crushed, ground, blended and screened) to make products such as road sub-base, which can then be sold back to the market as a non-waste.

The UK Landfill Directive Regulations $(2005)^{13}$, which implemented the EU Landfill Directive (1999) ${ }^{14}$, aimed to reduce reliance on landfill as a disposal option: "[in 2005] the market stalled on disposal. ...because the way [waste] was characterised changed and the availability of landfill void space dramatically reduced" [interview 17]. The regulatory framework is supported by other market based instruments such as the Landfill Tax (a tax on material disposed of at landfill, first introduced in 1996) and the Aggregates Levy (a tax increasing the cost of virgin (i.e. first used) aggregate, first introduced in 2002) ${ }^{15}$. Both the Landfill Tax and Aggregates Levy are designed to encourage the re-use of materials. Depending on the source or intended end use of extracted materials, other regulations such as the Water Framework Directive $2000^{16}$, Hazardous Waste Regulations 200517, Classification,

\footnotetext{
9 http://www.legislation.gov.uk/uksi/2010/675/pdfs/uksi 20100675 en.pdf, last accessed November 2018

${ }_{10}$ At the time of the study, August 2017, the cost of a recovery permit was around £2.65/tonne, compared to around $£ 84.40 /$ tonne for disposal to landfill.

11 https://www.claire.co.uk/projects-and-initiatives/dow-cop, last accessed November 2018

$12 \mathrm{http}: / /$ www.mineralproducts.org/documents/aggregates quality protocol.pdf, last accessed November 2018

13 http://www.legislation.gov.uk/uksi/2005/1640/pdfs/uksi 20051640 en.pdf, last accessed November 2018

$14 \mathrm{http}: / /$ ec.europa.eu/environment/waste/landfill index.htm, last accessed November 2018

15 https://www.gov.uk/green-taxes-and-reliefs, last accessed November 2018

16 http://eur-lex.europa.eu/legal-content/EN/TXT/?uri=CELEX:32000L0060, last accessed November 2018

17 http://www.legislation.gov.uk/uksi/2005/894/pdfs/uksi 20050894 en.pdf, last accessed November 2018
} 
Labelling and Packaging regulations $2008^{18}$ can affect the management of extracted materials. Moreover, the environmental regulatory framework works in conjunction with - but "not always in parallel" with [interviews 4,8,27] - the planning system. As interviewee 27 explains, "...basically the local authority runs the human health side and the planning side; the Environment Agency is the waste regulator". The Town and Country Planning Act $(1990)^{19}$, regulates the development of land in England and Wales, and the Planning Act $(2008)^{20}$, focusing on new infrastructure, place demands and restrictions on projects that generate extracted materials [interview 21].

Despite this stringent, multi-instrumental policy framework, evidence suggests that the regulatory framework has not had the intended outcome. Whilst construction and demolition waste sent to landfill has decreased over the last decade, extracted material sent to landfill has increased (Adams, 2014). The increase in extracted materials sent to landfill contributed to the sector missing the UK Government's 2007 Strategy for Sustainable Construction aim of halving waste to landfill by 2012 . WRAP's (2013) report into the factors driving the increase in extracted waste identified changes in the regulatory framework, in particular the new waste permitting arrangements, as primarily responsible. Interviewees supported this interpretation, referring to a regulatory framework that was, in their opinion:

- inflexible e.g. "tricky to balance the short term negative effects with the long-term positive effects" [interview 11]; "...the Agency can be tempted to take a very narrow view and impose regulation to protect one very specific small element of the environment, and in doing so slams the door on a much wider potential gain." [interview 5];

- insufficiently enforced "by an under resourced regulator" [interview 4, sentiments echoed in interviews 2,5,22,27], giving rise to illegal uses of waste, for example, exceeding tonnage or contaminating soils by mixing in other materials [interview 24];

- complex e.g. "the main challenge is understanding whether or not the materials are to be considered waste and therefore what regulatory controls are relevant to the handling/reuse/treatment of that material' [interview 14, sentiments echoed in interviews 10,17,22,27];

- $\quad$ onerous e.g. "the process of obtaining permits can be extremely difficult [interview 19], "extremely painful..., even when you are putting clean London clay from deep excavations into an excavation in London clay in an old quarry" [interview 4]; "death by a thousand emails" [interview 5]; and

- disproportionate e.g. "a lighter touch is needed for natural occurring soils, sub-soils, rocks where there is no reason to suspect man-made contamination of any significance, so organisations are not put through the full rigmarole of pre-assessment, or degree of very complex technical assessment and engineering proposal" [interview 5, sentiments echoed in interviews 4,13].

Whilst the regulatory framework attempts to incentivise and facilitate the re-use of extracted materials, primary and secondary evidence suggest that it is not working effectively. In the next section we report

18 http://eur-lex.europa.eu/LexUriServ/LexUriServ.do?uri=COM:2007:0355:FIN:EN:HTML, last accessed November 2018

${ }^{19} \mathrm{http} / / / w w w . l e g i s l a t i o n . g o v . u k / u k p g a / 1990 / 8 / \mathrm{pdfs} / \mathrm{kkpga} 19900008$ en.pdf, last accessed November 2018

20 http://www.legislation.gov.uk/ukpga/2008/29/pdfs/ukpga 20080029 en. pdf, last accessed November 2018 
our findings on how the roots of regenerative eco-innovations in extracted materials are affected by wider contextual conditions.

\subsection{Roots of regenerative eco-innovations in extracted materials}

Interviews with contractors, consultants, clients and regulators [e.g. interviews $2,4,5,6,7,9,10,11,12,13,14,17,21,24,27]$ considered the legislation and accompanying regulation as a key driver of innovation in extracted material use. Before the introduction of the key legislation and regulation noted above, end uses of uncontaminated extracted material (i.e. sub-soils) were often inert landfills in quarry locations and golf courses to raise levels of land [interview 2,4,5,10,13,14,15,24]. Extracted material was known colloquially as "muck away" [interview 16] (by way of explanation: "every developer will say: I've got this muck and I just want it away'). Interviews revealed various types of ecoinnovation in extracted materials that were stimulated by the regulatory framework and which contribute to regenerative development. For example:

- new technical processes including stabilisers, binders, thermal treatments, chemical oxidation, enzyme treatment, soil washing and screening, that support the re-use of extracted materials, [interviews 1,2,6,9,19,22,24];

- new uses of extracted materials including re-use on site as backfill (e.g. cofferdams [interview 6]), filling in voids off-site (e.g. chalk lakes [interview 6]) or supporting Environment Agency regenerative development projects (e.g. flood risk engineering projects, habitat creation [interview 5]);

- new intermediary organisations such as CL:aire, set up (by government, now member funded) to bring together government and industry to address common problems and to restore faith in soil/ground remediation by standard setting (e.g. DOWCOP), establishing a register of materials (facilitating the multi-site use of extracted material), raising awareness through peer reviewed best practice, providing training for industry and bringing together a community of practice around the re-use of extracted materials [interviews $10,14,15]^{21}$;

- entrance into the industry of organisations offering new routes for dealing with contaminated materials, such as Biogenie ${ }^{22}$ and Provectus ${ }^{23}$ that take soil, treat it and sell back to the market [interview 24];

- new inter-organisational arrangements between clients and contractors, such as the 'Extracted Materials Options Appraisal' (EMOA) methodology, developed on the Thames Tideway ${ }^{24}$ project. This approach for ensuring beneficial re-use of extracted materials was developed early on in the project, agreed with the regulators and planners and transferred to contractors with legally binding

\footnotetext{
${ }^{21}$ According to interviewees, CL:aire has since become an "industry focal point....sitting between Government and industry to map out and understand common industry problems or failings and look to design solutions such as DOWCoP" [interview 10] and was described as being "singularly important in helping reuse materials on development sites" [interview 14].

22 http://biogenie.co.uk, last accessed November 2018

23 https://www.provectusgroup.com, last accessed November 2018

24 Thames Tideway is a mega infrastructure project in London that will move 4.5 million tonnes of extracted material in 2018/19. See https://www.tideway.london, last accessed November 2018
} 
KPIs (e.g. targets for diversion from landfill, beneficial use of extracted material, moving more materials by river [interviews $3,11,12$ ]).

- new intra-organisational arrangements for contractors including waste/materials management plans [interview 9], pre-demolition and pre-redevelopment audits [interviews 8, 9].

Interviews referred explicitly to the role of central government (e.g. Department of Environment, Food and Rural Affairs, and HM Revenue and Customs, who administer the levies), local authorities and the regulator (Environment Agency) as the key actors affecting eco-innovative uses of extracted materials to support regenerative development [interviews 2,5,6,9,10,11,13,14,16,17,19,21,22,24,27]. Interviewees also referred to the important contribution of other actors. For example, trade associations, such as Build UK and member organisations such as CL:aire, [interviews 9,10,11,19,27]; clients, especially of 'mega' projects that can look beyond economic cost, take early decisions on waste management and can re-use extracted materials at other site(s) [interviews $2,4,5,6,10,11,12,16,17,21]$; consultants who have expertise on the regulatory framework and can "design in and out waste" [interview 17, also mentioned in interview 16]; large contractors, especially if they are involved early in the construction/demolition process and/or respond to specifications requiring eco-innovative solutions, and especially when remuneration is linked to waste targets of the client [interviews 9,11,16,17,24]; private, public and third sector organisations with large land holdings [interviews 5,15]; and waste management companies who "influence the management, treatment and disposal or recovery of material... because it's their margin that's at stake" [interview 17].

Interviews revealed some specific cases where product, process and organisational eco-innovations had combined, more closely matching the concept of regenerative development (Cole, 2012; Mang and Reed, 2012). Interviewees [interviews 3,4,5,17,24] spoke of the central role of extracted materials in the creation of enhanced wetland habitats or enhanced public parklands, providing amenity access land for the public whilst supporting biodiversity and engaging local/national stakeholders. Northala Fields Park in north London is a good example. In 1997, Ealing Borough Council bought Northala Fields Park, at the time a derelict site running alongside the main arterial road from London to Oxford and Birmingham, with the intention of redeveloping the 45-acre site into a new park. In the early 2000 s, consultants recruited to the project proposed the idea of shielding the main part of the park from the noise, visual and air pollution of the main road with the creation of four man-made hills. Work on the 'monumental landform' began in 2004 using extracted materials and other construction and demolition waste from major civil engineering works in west London including Heathrow Terminal 5, White City and Wembley Stadium. Operating within the EU Landfill Directive and incentivised by the Landfill Tax, the project proposed to accept spoil at the Northala Fields site, charging a 'gate fee' of between $£ 70$ and $£ 90$ per lorry load (BBC News, 2008). Developers of the major civil engineering projects saved both money and time, and reduced their ecological impact by hauling their site's spoil to Northala Fields, a fraction of the distance to the nearest landfill site. It was reported that approximately sixty thousand lorryloads of spoil and concrete were accepted at Northala Fields during the project (BBC News, 2008; Cartiere, 2009). The spoil was used to create the four landforms while the concrete was 
crushed and used in one mile of gabion baskets (walls surrounded by steel cages, providing a spiral path up the hills). When the Park was completed in 2008, total gate fees for imported materials more than covered the $£ 5.5 \mathrm{~m}$ project costs. Design of the project closely and iteratively involved the local community, helping to overcome initial hostility to receiving waste (BBC News, 2008; Cartiere, 2009). The Park contributed social added value by providing new recreation opportunities (playgrounds, model boating lake, urban fishing lakes, cycling pathways). In addition to the re-use of extracted and construction materials, environmental value added also stemmed from diverse new ecological habitat creation, including meadow and grassland, woodland and wetlands; by using varying soil conditions in each of the mounds, the landforms themselves support diverse wildflowers. ${ }^{25}$

The 'Wallasea Island Wild Coast Project' in Essex is another example of a restorative and regenerative project. The Royal Society for the Protection of Birds (RSPB), the UK's largest nature conservation charity, acquired Wallasea Island in the early 2000s. In 2008, RSPB were approached by Crossrail, a major infrastructure project to build new railway connections under central London, who were seeking a beneficiary to reuse the clean spoil from their excavation of tunnels, stations and shafts (Paris et al., 2017; RSPB, 2018). Legal requirements controlling the deposition of extracted materials were rooted in the WFD (Directive 2008/98/EC), the EU Landfill Directive (Directive 1999/31/EC) and the EU Council Decision 2003/33/EC, and the corresponding UK environmental permit regulations (Davis and Melling, 2015). Following consultation with the Environment Agency, a bespoke risk based Environmental Permit for waste recovery was adopted, allowing deposits of extracted materials to be made at Wallasea Island subject to contamination screening (e.g. screening for tunnelling additives and naturally occurring elements), preventing risks to the aquatic environment (Cross, 2017) ${ }^{26}$. Between 2012 and 2018, more than three million tonnes of extracted material from the Crossrail project were transported (mainly by rail and river, taking 150000 haulage lorries off the road) to Essex to raise part of the island by 1.5 metres, create lagoons and other wildlife-friendly features, and protect these areas with new sea-walls (Brownfield Briefing, 2016). The central aims of the project were to offset historic losses of coastal habitats and offer flood protection, returning the area to the coastal marshland it was 400 years ago ${ }^{27}$. Helping to adapt to climate change on the coast was an additional environmental objective, and the project also targeted job creation and protection, and increased recreational opportunities (ABPmer, 2008). Recent evaluations suggest that wildlife has started to return with avocets and ringed plovers, wintering Brent geese and birds of prey now a common sight at Wallasea Island (RSPB, 2018b).

\footnotetext{
25 For more information, see http://www.landezine.com/index.php/2011/06/form-landscape-architecture/; https://www.landscapeinstitute.org/case-studies/northala fields/;

https://www.ealing.gov.uk/info/201136/parks in the borough/663/greenford parks/2; all last accessed November 2018

${ }^{26}$ The aquatic environment is critical at Wallasea, and any depositions of extracted materials were governed also by the EU Water Framework Directive (Cross, 2017).

${ }^{27}$ https://www.rspb.org.uk/reserves-and-events/find-a-reserve/reserves-a-z/reserves-byname/w/wallaseaisland/about.aspx; http://www.crossrail.co.uk/construction/tunnelling/excavated-material, both last accessed November 2018
} 
The Wallasea Island project would not have been possible without multiple eco-innovations supporting the re-use of extracted materials, which, due to operational constraints and timescales, would have typically gone to landfill. The development of bespoke processes such as the 'Rapid Measurement Techniques' for on-site testing and 'Smartwaste' system to track the waste across the project, and the creation of new infrastructure to support more sustainable transport of the extracted materials by rail and river, were all recognised in the award of 'Best re-use of materials on a project' at the Brownfield Briefing Awards in 2016 (Brownfield Briefing, 2016). The importance of early and wide collaboration with stakeholders was highlighted by many analysts as another key ingredient in the project (Plimmer, 2015; Cross, 2017; Paris, et al., 2017; RSPB, 2018a,b).

Although Northala Fields Park and Wallasea Island represent examples of the regulatory framework facilitating eco-innovations that support regenerative development, they remain isolated examples. Section 4.1 emphasised the shortcomings of the regulatory roots and interviews offered insights into how the wider contextual conditions in the UK built environment sector also hinder wider diffusion of regenerative eco-innovations. In the following paragraphs, we group these challenges into four categories of structural constraints: economic, technical, organisational and institutional.

Economic constraints are widely thought to hinder the re-use of extracted materials. In their review of the factors facilitating and hindering the re-use of construction, demolition and extraction waste in UK built environment sector, Adams et al. (2017) report a lack of market mechanisms to aid greater recovery of extracted materials as a significant barrier. Our interview findings support Adams et al.'s conclusions. Whilst there has always been a market for top-soil, interviewees report little demand for sub-soils [interviews 2, 24]. Fewer recovery permits are being granted [see section 4.1], increasing the already high distribution costs of extracted materials going for disposal [interviews $12,13,16]^{28}$. Moreover, the lack of sites suitable for recovery and disposal facilities create knock-on effects, further hindering re-use of extracted materials [interviews $8,11,12,14]$ ]: "The challenges faced by waste management, are not only the costs of removing it, but on some sites where space is restricted or there's a push from logistics - for example, the number of wagons going in and out of the site on any given day - then the waste influences things like noise and traffic movements and so on" [interview 17].

Interviewees argued that technical challenges persist regarding knowledge and understanding of waste, and the quality of extracted material. Knowledge and understanding is thought to vary both within the regulator [interviews 5,17,22] - "the patchy knowledge of the regulators can prove challenging because what is done more commonplace in the south east might not be in the south west or in the north [of England and Wales]" [Interview 5] - and across industry [interviews 10,11,16,17,22]. This presents challenges for the organisation responsible for ensuring waste is dealt with appropriately, usually the client or main contractor, including when to bring in expert knowledge from

\footnotetext{
${ }^{28}$ Several interviewees reported that the cost of distributing extracted material is estimated to be the second highest cost after the regulatory compliance costs.
} 
beyond the organisation [interviews $8,9,10,16,27$ ]. The process of extraction also presents some technical barriers. For example, additives to assist the process of extraction activity can 'contaminate' or 'destabilise' the extracted material, making it geo-technically unsuitable for certain end-uses or costly to treat before re-use [interviews $2,3,5,16,17$ ]. As interviewee 17 explained, "The material that gets squidgy and slurrified comes from polymer added to deconstruct the material so you can push it through the TBM [tunnel boring machine] and onto the conveyors...once you've tunnelled it, you want exactly the opposite properties, but...you cannot get it back out. You've already impacted the structure or the integrity of the material; you would not want that material as a flood defence." Another technical challenge of the process of extraction on 'mega' infrastructure projects is the momentum required: "once you start tunnelling, you cannot stop" [interview 11], which "...places a burden on the infrastructure market and the logistics market" [interview 17]. Volume also places technical constraints on the end-use of extracted materials: "[Large] volumes are barriers to quirky solutions...you won't find any major construction project, that is dealing with millions of tonnes of material [that are] able to rely on those sorts of solutions (like "blockwork" [interview 3]; or "toothpaste" [interview 12]).

At the organisational level, interviewees raised challenges associated with companies sharing information in a meaningful timeframe with other parts of the business, or with third parties [interviews $4,5,8,10,21,27]$. Whilst Paris et al. (2017) highlight the good practice mechanisms for knowledge sharing on the wider Crossrail project, interviewees acknowledged the inherent difficulties. An initiative developed by a major housebuilder to share soils and extracted materials within and between business units, for example, was considered only partially successful by its originator. The lack of success was attributed mainly to the nature of contractual arrangements and the normal ways of working: "the vast majority of earthworks contracts or remediation contracts or demolition contracts that are issued by house builders are on fixed lump sum or risk type basis, so we basically give the problem away to a third party. Provided the number for that contract is less than the number in the cost plan, our guys are more than content to make the margin. Whereas what [our initiative] demands of them is thinking again, taking control of that material, taking control of the risks of that material, and doing something with it to squeeze out some extra value. And a lot of people don't want to do that, and you can sort of understand why: we're not specialist earthworks contractors, there is a lot of pitfalls and problems that could occur with it" [interview 27].

At an institutional level, an underlying challenge that reflects deeply embedded norms across the industry and society is for industry to see waste as a resource [interviews $9,10,16$ ] rather than "muck away", and for the fears of the public about the re-use of contaminated extracted material to be allayed [interview 18]. Interviewees also reported that stimulating the re-use of extracted materials is, to some extent, hostage to the characteristics of the construction and demolition sector: low profit margins, project based, bespoke product, temporary networks, some unscrupulous actors [interview 10,8,21]. Furthermore, stimulating change among the actors involved in the 'mega' infrastructure projects is one challenge, arguably a greater challenge resides with influencing the "huge tail of small volumes" [interview 16] of extracted materials. 


\section{Discussion}

In section 4 we presented our findings on the regulatory context and the roots of regenerative ecoinnovation in the use of extracted materials. In section 5.1 we compare and contrast our findings of the case with the literature on the effectiveness of regulation for stimulating regenerative eco-innovation. In section 5.2 we consider how the roots of regenerative eco-innovations are affected by other contextual conditions, comparing our economic, technical, organisational, and institutional structures with previous frameworks.

\subsection{Effective regulation for regenerative eco-innovations}

Our findings reveal a stringent, multi-instrumental regulatory framework that combines sectoral targets for diversion from landfill of extracted materials and a fiscal regime designed to incentivise re-use, with direct regulation and voluntary codes of practice supporting end-use of extracted materials without waste management controls. Veugelers (2012) provide empirical evidence that the leverage of government policy increases when regulation is combined with other instruments like taxes and subsidies. Ribeiro and Kruglianskas (2015) came to the same conclusion about the relative effectiveness of multi-instrumental policy. Studies over the past three decades maintain that effective regulation can be characterised as stringent, flexible and enforceable (e.g. Huber, 2008; Mickwitz et al., 2008; Popp et al., 2011; Kesidou and Demirel, 2012; Horbach et al., 2012; Auld et al., 2014; and Dong et al., 2014 amongst others). Recent studies have emphasised the relevance of regulatory stringency. For example, Hojnik and Ruzzier's (2016) meta-analysis of the drivers of eco-innovation note that stringent regulation is important both for the development and adoption of eco-innovation. Arfaoui et al. (2014) argue that stringency is the single most determining feature of regulation to spur ecoinnovations, mainly because, as Cai and Zhou (2014), Costantini et al. (2015), Yang and Yang (2015), Yuan et al. (2017) amongst others note, stringent regulation stimulates eco-innovation that reduces the cost of compliance.

In our case, whilst we observe stringency, the regulatory framework appears to come up short in terms of flexibility and enforcement. Flexibility is often mentioned in studies of regulatory quality, though it is not always clearly defined. For Rothwell (1992), flexibility reflects regulation that is not prescriptive about the compliance technique; for Arfaoui et al. (2014), Auld et al. (2014), Ribeiro and Kruglianskas (2015) and Zhao and Sun (2016) this recognises that organisations have different marginal abatement costs and gives them flexibility in how they achieve regulatory goals. When our interviewees talked about the regulatory framework being inflexible, they were reflecting on the interpretation of the regulation rather than the regulation per se (see the 'inflexibility' quotes concerning the role of the regulator from interviews 5 and 11 in section 4.1 above). Indeed, there was a general perception that the "imprecise...flawed" [interview 4] regulatory framework struggles to encourage recovery and re-use whilst ensuring that extracted materials are not polluting. The ramifications of a recent legal ruling highlight how inflexibility in the interpretation of the EU Waste Framework Directive could hold up future regenerative eco-innovations opportunities for extracted materials [interviews 2,4,7,10,12,13,14; Cross, 
2017; see also the commentaries cited in the footnote ${ }^{29}$ ]. The legal case between Tarmac Aggregates Ltd (a building materials and construction contractor) and the UK government in 2016 contrasted two tests of the EU Waste Framework Directive: 1) the 'by-product test', defined as a "production residue that is not a waste"; with 2) the 'substitutability test', which requires the end-user of the waste to be willing to pay for new materials if extracted materials are not available. The Environment Agency refused Tarmac Aggregates Ltd a recovery permit on the basis of the second test. This was later supported by the UK Government and although the decision was overturned on appeal, one consequence was that the Environment Agency effectively stopped issuing recovery permits. In the opinion of one interviewee, the interpretation of the ruling "placed an unfair burden on legitimate organisations who could have offered capacity of void space for reused material, and now can't because of having to demonstrate the financial means to use non-waste [virgin] material" [interview 17]. The legal ruling had implications for an owner/operator on a recent mega infrastructure project in the UK that planned to re-use extracted materials in a manner akin to the Crossrail project: “...the unique selling point that those ecological sites had, was that they were free from landfill tax. So, it made sense to take extracted materials to them, and there was a win/win: a win for the ecology stakes for the site, [where] you'd be lowering the water levels of deep lakes to create good habitats for birds, or [where] you'd be filling in chalk quarries, with other chalk material to create grassland. The quid pro quo was [that] the contractor did not incur landfill tax...the change in regulation interpretation entirely undermines the rationale of [similar] schemes" [interview 12]. In that specific instance, the ruling meant significantly more work for the owner who then had to apply for a disposal permit for water rather than a recovery permit for habitat creation, with more "administrative hoops to jump through" [interview 17, sentiments echoed by interviewees 11,12]. More generally, the "loss of the mechanism of using a recovery licence has caused lots of confusion" [interview 5], increased costs and held up opportunities for the beneficial use of extracted materials elsewhere [interviews $2,4,5,11,12,13,14,24]$. Indeed, the Court of Appeal judge recorded that had the ruling been made earlier, it would have been unlawful for schemes such as Wallasea Island to receive a recovery permit. This demonstrates that the interpretation of the regulatory framework can limit the re-use of extracted materials and disincentivise the development and diffusion of associated regenerative eco-innovations.

Enforcement is another key characteristic of high quality regulation (Rothwell, 1992; Demirel and Kesidou, 2011; Auld et al. 2014; Ribeiro and Kruglianskas, 2015). As with flexibility, evidence from our case suggests that the problem with enforcement seems not be the regulation per se, which uses a system of environmental permits to set specific requirements for industry to meet, but rather one of implementation from an "under resourced regulator" [interview 4, sentiments echoed in interviews $2,5,22,27]$. A number of interviewees mentioned 'unscrupulous actors' in the industry whose actions go unchecked by a lack of enforcement. For example, Interviewee 24 argued that permits could be abused by either exceeding the tonnage (e.g. "waste contractors having 15000 tonnes when they should just

29 See http://www.mineralandwasteplanning.co.uk/laying-down-law-backfilling/article/1411217 and http://www.localgovernmentlawyer.co.uk/index.php?option=com content\&view=article\&id=25140\%3Atarmacwins-court-of-appeal-battle-over-quarry-restoration-and-waste\&catid=63\&ltemid=31, both accessed November 2018 
have 5000: there's lots of skulduggery that goes on because of that financial incentive to keep their disposal at $£ 2.50$ a tonne") or mixing into soils other waste materials (e.g. "what would cost $£ 80$ a tonne if you can shred plastic bags and if you can crush plasterboards, and if you can get rid of your trommel fines and mix it in with some soil and then send it to a golf club or something like that then no one is non-the-wiser").

Consistent with previous studies, our findings point to other limitations of the regulatory framework. Many interviewees $[4,5,10,14,17,19,22,27]$ thought the regulatory framework was still too complex, onerous and dis-proportionate. Our interviews suggested that this was driven by varying levels of knowledge and understanding across industry practitioners [interviews 5,17,22], but also complicated by the inconsistent support offered by the regulator operating in different parts of the UK [interviews $5,10,11,16,17,22]$. This finding resonates with Rothwell (1992), who noted how unclear regulations and the competence of regulatory bodies affects the subsequent actions of industry. Interviewee 17 summed up the situation by calling for "any [change] that means [the regulatory process] is more accessible and easier to understand and easier to get the green light". Simplicity and clarity, allowing regulations to be easily understood and met, is one of Ribeiro and Kruglianskas' (2015) principles of regulatory high quality and one of Auld et al.'s (2014) policy design characteristics for regulation with lasting consequences.

Overall, our findings suggest that the current regulatory framework for extracted materials could be characterised as somewhat inflexible, insufficiently enforced, complex, onerous and disproportionate. If we measure the effectiveness of regulation by the capability to produce the desired effect, as Auld et al. (2014) propose, then these characteristics can be seen to undermine the consequential effectiveness of the regulatory framework to facilitate the re-use of extracted materials. These characteristics are not unique to this case but reflect underlying limits to environmental regulation, such as regulatory efficacy (i.e. setting the correct target and ensuring targets are met) and economic efficiency (i.e. imposing high costs of compliance/abatement costs for industry and administration/enforcement costs for the regulator) (Ribeiro and Kruglianskas, 2015). What is different in our case is that we are concerned with regenerative eco-innovations, which Hofstra \& Huisingh (2014) define as those innovations that "restore, renew [and] revitalise" natural systems. Regenerative development relies on built environment stakeholders embracing strategies that increase natural and social capital, not only preserving and protecting, but restoring a lost plenitude (Du Plessis, 2012; van der Ryn and Cowen, 2007). When selecting an appropriate case for this research, eco-innovative uses of extracted materials appeared a priori to share characteristics with regenerative eco-innovations. Insights from our study support this assertion and our interviews revealed a few isolated examples where extracted materials had been used to create added value for humans and nature and to 'restore a lost plenitude'. A high quality regulatory framework for regenerative eco-innovations would facilitate a shift away from current green trajectories (in our case, for example, higher targets for landfill diversion) toward strategies that promote regenerative development (in our case, for example, to stimulate ecoinnovations in extracted materials to increase natural and social capital). One can conclude that the 
current regulatory framework needs to be revised to allow for implementation that is more flexible (especially in the interpretation of the regulator), better resourced and enforced, simpler and less onerous, and proportionate. Before change occurs in the implementation of the regulatory framework, we are unlikely to see widespread diffusion of the types of eco-innovation associated with radical, architectural change that are needed for regenerative development. Our study also reveals that other distal conditions weaken the roots of regenerative eco-innovations, and it is to these conditions where we turn our attention now.

\subsection{Roots of regenerative eco-innovations}

Our case sheds light on how a set of inter-related eco-innovations, consistent with regenerative development, can have their roots in the regulatory framework. Eco-innovations essentially boil down to new ideas (products, processes, organisational approaches, new intra/entrepreneurial ventures) that contribute to a reduction of environmental or social burdens, or to specified sustainability targets. From their meta-analysis of 155 studies, Hojnik and Ruzzier (2016) conclude that regulations constitute the most commonly and frequently reported trigger of eco-innovations. Many studies have reported a positive relationship between regulation and product, process and organisational eco-innovations (for recent examples see Triguero et al., 2013; Horbach, 2012, 2016; Penasco et al. 2016; Ramanathan et al. 2016; Castellacci and Lie, 2017; Cai and Li, 2018; You et al., 2019). Our findings are consistent with these studies and our case offers examples of different types of eco-innovations stimulated by the regulatory framework. Some of the process innovation examples meet the characteristics of 'cleaner production' technologies, such as new treatment techniques for extracted materials. We also see organisational eco-innovations, such as new arrangements for procurement and interactive supplierclient relations, that represent step changes when compared to previous interactions. Previous studies have found this type of innovation to be less common (Hellstrom, 2007; Wagner and Llerena, 2011) as it requires more fundamental (i.e. radical/architectural) change in routines of organisations. Facilitating step change innovations is one aspect of high quality regulation (Rothwell, 1992) and is consistent with the demands of regenerative development (Mang and Reed, 2012; Cole, 2012). We would expect to see more radical/architectural type of eco-innovations with a revised, more effective regulatory framework.

We also see examples of new intra/entrepreneurial ventures launched in response to the changing regulatory framework, such as CL:aire ${ }^{30}$, an independent not-for-profit organisation, established in 1999 to stimulate the regeneration of contaminated land in the UK by raising awareness of, and confidence in, practical and sustainable remediation technologies. However, our case also reveals where the regulatory framework hinders new entrepreneurial ventures. At present, when an extracted material is classified for recovery, it is considered to be a non-waste but is placed in-situ in perpetuity; when a material is classified for disposal, it is considered to be a waste until the Environment Agency, Planning Authority and operator sign off after care permits. Several interviewees [interviews 15,16,17,27]

\footnotetext{
${ }^{30}$ https://www.claire.co.uk, last accessed November 2018
} 
proposed a third way, in between recovery and disposal, involving "landbanks at locations around the UK, where material is not simply just consigned to a site and left there forever, but it can go there and be re-accessed at some later date" [interview 15]. Locations of the landbanks were deemed critical: sites would need to be accessible for future infrastructure projects, close to transport networks, and/or near vulnerable flood sites. An operator would vet the material on delivery, handle (e.g. screen, crush) and perhaps treat the material, consign it by type or quality and use the material to fill a void in a way that would be accessible later; a fee would be charged at the point of delivery and again when the material was re-accessed; the operator would be responsible for the material for a pre-determined period. Interviewees thought moving into this innovation space might be organisations from the mineral and quarry sector who own land, have voids to fill, have equipment for handling materials, and the scientific and administrative expertise for accepting and handling material before returning it to the market in the short-term (e.g. sands, gravels) or long-term (e.g. chalks, clays). This combination of ecoinnovations, consistent with regenerative development, would require regulatory change to allow extracted material to be stored without being classified as recovery or disposal for longer than the current maximum of three years; the material would then be accessible in the future to meet emergency or special interest, for example, regenerative development projects.

The regulatory roots of regenerative eco-innovations were reflected in the identification of the legislator, regulator and planning authorities as key actors in eco-innovative uses of extracted materials. There was also wide acknowledgement that innovation was a multi-actor endeavour requiring a "combined effort between government, regulatory bodies and industry representatives" [interview 14]. This fits with the idea of eco-innovation as a social process involving a wide variety of individuals and organisations (Boons and Wagner, 2009). It appears to be especially relevant for ecoinnovations in the built environment sector, a highly regulated, fragmented and project based industry, referred to previously as the "archetypal network system" (Miozzo and Dewick, 2002, p.70). In our case, what the examples of regenerative development projects show is that wide engagement is required with stakeholders with relevant and legitimate interests in, for example, the natural environment and other species. In the examples of Northala Fields and Wallasea Island, the projects had wide engagement with stakeholders and an explicit consideration of natural and social capital in the design and delivery of the projects. This brings us closer to the concept of regenerative development discussed by Du Plessis (2012) and Hofstra and Huisingh (2014). Although this is undertaken routinely in natural capital initiatives (Helm, 2015), it is not yet standard across the built environment sector and is compromised by the characteristics of the regulatory framework and the wider contextual conditions.

What our case also reveals is that regenerative eco-innovations are different from traditional ecoinnovations in terms of intention. Dewick and Foster (2018) note the uncertainty in the literature around whether intention is a necessary component of eco-innovation. Whilst some, such as Rennings et al. (2013), make it clear that eco-innovations "may be developed with or without the explicit aim of reducing environmental harm" (p.333), in the case of regenerative eco-innovations, the necessity for 
early and broad multi-actor stakeholder engagement and requirement of radical and architectural changes to products, processes, organisational arrangements and institutions, means that intention is a prerequisite for regenerative development.

Our case also shows how the adoption and diffusion of an inter-related set of eco-innovations consistent with regenerative developments can be held up by wider contextual conditions. Identifying these system level conditions is an important step forward in addressing and overcoming barriers to change. In the case of extracted materials, the regulatory roots are inherently weak and further hindered by unsupportive contextual conditions. We categorise these conditions as economic (e.g. low revenues/high costs), technical (e.g. imperfect knowledge), organisational (e.g. collaboration challenges) and institutional (e.g. socio-cultural norms and industry characteristics) constraints. These conditions share similarities with other conceptualisations of the factors that determine ecoinnovations, for example the frameworks of Rennings (2000), Horbach (2008) and Cecere et al. (2014). If we take Rennings' (2000) framework, our regulatory roots fit Rennings' regulatory push factors, our technical and organisational influences fit broadly the technology push factors, and our institutional constraints fit broadly the market pull factors. Similarly, if we take Horbach's (2008) framework, then our technical and organisational constraints echo Horbach's supply side factors, our economic constraints fit the demand side factors, and our regulatory and institutional roots are captured by Horbach's institutional and political influences. Cecere et al. (2014) analyse the factors that cause lock-in and path dependency and point to cost related, technology/knowledge related and stakeholder related factors. Cost related factors emerged clearly in our case: our interviewees referred to cost disadvantages of being innovative with extracted materials, coupled with a lack of demand and absence of infrastructure to manage large volumes. Some of the technical and organisational barriers to radical, architectural eco-innovations that are characteristic of regenerative development are reflected in Cecere et al.'s technology/knowledge related factors, though some constraints (such as the inter- and intra- organisational issues reported above in our findings) spill over into their category of stakeholder related factors. Regulatory roots and institutional constraints fit into this final category as well. The observation of interdependency and inter-relatedness in the contextual conditions is not a surprise and is why sustainable change must be studied at the systems level and include an understanding of the role of actors, networks and institutions (Vergragt et al., 2014). It also emphasises that revising the regulatory framework is a necessary but not sufficient condition for achieving wide diffusion of eco-innovative practices consistent with regenerative development.

\section{Conclusion}

The aim of our research is to explore the role of the regulatory framework and wider contextual conditions in facilitating or hindering regenerative eco-innovations. Our objectives were two-fold: 1) to consider the role of regulation in stimulating regenerative eco-innovations; and 2) to consider how the roots of regenerative eco-innovations are facilitated or hindered by wider contextual conditions. In a case study of extracted materials in the built environment sector in the UK, a sector that is highly regulated and where rates of innovation are typically slow, we combined a secondary analysis with an 
interview programme involving 30 stakeholders. Case studies are often criticised for not allowing generalisations to be drawn from their analysis. Ridder et al. (2012) argue that "case study findings can provide a theoretical contribution if they challenge, change or fundamentally advance our understanding of a phenomenon or initiate new theory". Regenerative eco-innovations have not previously been explored in-depth and in this paper, we extend and elaborate the eco-innovation literature in two ways. First, we shed light on the relationship between regulation and regenerative eco-innovation. Our case shows that the current UK regulatory framework for extracted materials does not adequately support regenerative eco-innovation. Whilst the framework can be characterised as multi-instrumental and stringent, it is also inflexible and under-enforced, onerous and disproportionate. These characteristics undermine the consequential effectiveness of the regulatory framework to stimulate regenerative ecoinnovation. The brittle regulatory roots of regenerative eco-innovation are not solely responsible however, and our second contribution illustrates constraints in the contextual conditions that hinder regenerative eco-innovations. We identify economic, technical, organisational, and institutional conditions that act as barriers to the adoption and diffusion of regenerative eco-innovations. By understanding the contextual conditions maintaining the status quo, our case shows that a focus on regulatory change will not be enough to chart a pathway toward regenerative development. Whilst there is a need for further work, our paper contributes to a more grounded understanding of regenerative ecoinnovation processes and responds to the calls of Hofstra and Huisingh (2014) for more empirical work to support theory building, and Hojnik and Ruzzier (2016) for elaboration on the distal contextual conditions that facilitate and hinder eco-innovations. We call for more studies of the roots of regenerative eco-innovations in different contexts.

Our paper also has practical utility. It contributes to a better understanding of how to respond to the global challenge of closing material cycles and reducing waste to landfill. Fellner et al. (2017) looked at five commodities that account for a major part of the material resources consumed in the EU28 (in terms of mass, energy demand and economic value), one of which was aggregates (i.e. sand and gravel). Their analysis indicated that consumption of materials far exceeds waste generation. For aggregates, even if all waste was recycled, only $20 \%$ of annual consumption could be substituted. Currently, less than half of that amount is substituted, equating to below $10 \%$ of present primary production (ibid.). Whilst this presents a space for regenerative eco-innovation, and our paper helps understand the challenges for the diffusion of inter-related product, process, organisational and institutional eco-innovations that combine to add value for humans and nature, there remain limits to closing material cycles. Tisserant et al. (2017), for example, calculated that 3.2 giga-tonnes (i.e. 3.2 billion metric tonnes) of waste were generated worldwide in 2007, of which nearly half was landfilled. Building on the previously acknowledged limits of economic, physical (i.e. contamination) and system wide trade-offs (cheaper/less energy intensive to use primary materials) (Gregson et al., 2015; Tisserant et al., 2017), our analysis contributes to this discourse by helping to understand how strategies to divert from landfill are also hindered by regulatory shortcomings and other contextual conditions at the sectoral level. 


\section{References}

ABPmer, 2008, Wallasea Island Environmental Statement, available at https://www.rspb.org.uk/globalassets/downloads/documents/campaigning-for-nature/wallaseaisland-environmental-statement.pdf, last accessed November 2018

Adams, K., 2014, CD\&E Waste: Halving construction, demolition and excavation waste to landfill by 2012 compared to 2008, available at http://www.greenconstructionboard.org/images/resources/Report\%2023\%20Waste.pdf, last accessed July 2017

Adams, K.T., Osmani, M., Thorpe, T., and Thornback, J., 2017, Circular economy in construction: current awareness, challenges and enablers, Waste and Resource Management, 170 (1), 15-24

Arfaoui, N., Brouillat, E., Saint Jean, M., 2014, Policy design and technological substitution: Investigating the REACH regulation in an agent-based model, Ecological Economics, 347-365, http://dx.doi.org/10.1016/i.ecolecon.2014.08.013

Auld, G., Mallett, A., Burlica, B., Nolan-Poupart, F., Slater, R., 2014, Evaluating the effects of policy innovations: Lessons from a systematic review of policies promoting low-carbon technology, Global Environmental Change, 29, 444-458, http://dx.doi.org/10.1016/i.gloenvcha.2014.03.002 .

BBC News, 2008, The hills of the future, available at http://news.bbc.co.uk/1/hi/magazine/7310211.stm, last accessed November 2018

Blind, K., 2012, The influence of regulations on innovation: A quantitative assessment for OECD countries, Research Policy, 41 (2), 391-400, http://dx.doi.org/10.1016/j.respol.2011.08.008

Boons, F. and Wagner, M., 2009, Assessing the relationship between economic and ecological performance: Distinguishing system levels and the role of innovation, Ecological Economics, 68, 19081914, doi:10.1016/j.ecolecon.2009.02.012

Brownfield Briefing (2016), Best Re-use of Materials on a Project: Wallasea Island Wild Coast Project, available at http://www.ecologia-environmental.com/wp-content/uploads/2017/11/Brownfield-BriefingAwards-Best-Reuse-of-Materials Wallasea-Island.pdf, last accessed November 2018

Cai, W., and Zhou, X., 2014, On the drivers of eco-innovation: empirical evidence from China, Journal of Cleaner Production, 79, 239-248, http://dx.doi.org/10.1016/j.jclepro.2014.05.035

Cai, W. and Li, G., 2018, The drivers of eco-innovation and its impact on performance: Evidence from China, Journal of Cleaner Production, 176, 110-118, https://doi.org/10.1016/j.jclepro.2017.12.109

Cartiere, C., Northala Fields: Valhalla in the distance, Journal of Urban Regeneration and Renewal, 3 (3), 324-300

Castellacci, F. and Lie, C.M., 2017, A taxonomy of green innovators: Empirical evidence from South Korea, Journal of Cleaner Production, 143, 1036-1047, http://dx.doi.org/10.1016/j.jclepro.2016.12.016 Cecere, G., Corrocher, N. Gossart, C., and Ozman, M., 2014, Lock-in and path dependence: an evolutionary approach to eco-innovations, Journal of Evolutionary Economics, 24, 1037-1065, DOI 10.1007/s00191-014-0381-5

Coenan L. and Diaz Lopez FJ, 2011, Comparing systems approaches to innovation and technological change for sustainable and competitive economies: an explorative study into conceptual commonalities, differences and complementarities, Journal of Cleaner Production, 18, 1149-1160 
Cole, R.J. 2012, Transitioning from green to regenerative design, Building Research \& Information, 40(1), pp.39-53.

Costantinia, V., Crespia, F., Martinic, C. and Pennacchiod, L., 2015, Demand-pull and technologypush public support for eco-innovation: The case of the biofuels sector, Research Policy, 44, 577595, http://dx.doi.org/10.1016/j.respol.2014.12.011

David, J. and Melling, L., 2015, The transport and beneficial re-use of Crossrail excavated material, Crossrail Learning Legacy, available at https://learninglegacy.crossrail.co.uk/documents/thetransport-and-beneficial-re-use-of-crossrail-excavated-material/, last accessed November 2018

Del Río González, P., 2009, The Empirical analysis of the determinants for environmental technological change: a research agenda, Ecological Economics, 68 (3), 861-878.

Demirel, P. and Kesidou, E., 2011, Stimulating different types of eco-innovation in the UK: Government policies and firm motivations, Ecological Economics, 70 (8),1546-1557, http://dx.doi.org/10.1016/i.ecolecon.2011.03.019

de Souza, W.F.J., Scur, G. and de Castro Hilsdorf, EW., 2018, Eco-innovation practices in the brazilian ceramic tile industry: The case of the Santa Gertrudes and Criciúma clusters, Journal of Cleaner Production, 199, 1007-1019, https://doi.org/10.1016/j.jclepro.2018.06.098

Dewick, P. and Foster, C., 2018, Focal organisations and eco-innovation in consumption and production systems, Ecological Economics, https://doi.org/10.1016/j.ecolecon.2017.07.012

Dewick, P. and Aylen, J., 2014, Sustainable innovation management: Ten lessons from innovation studies for a sustainable paradigm, in United Nations Global Compact International Yearbook, United Nations: Germany, 30-32

Dewick, P. and Miozzo, M., 2004, "Networks and innovation: Sustainable technologies in the Scottish social housing sector", R\&D Management, 34, 3. 323-334, https://doi.org/10.1111/j.14679310.2004.00342.x

Dewick, P. and Miozzo, M., 2002a, "Sustainable technologies and the innovation-regulation paradox", Futures, 34. 823-840, https://doi.org/10.1016/S0016-3287(02)00029-0

Dewick, P. and Miozzo, M., 2002b, "Factors enabling and inhibiting sustainable technologies in construction: The case of active solar heating systems", International Journal of Innovation Management, 6, 3. 257-276, https://doi.org/10.1142/S1363919602000598

Dong, Y., Wang, X., Jin, J., Qiao, Y., Shi, L., 2014, Effects of eco-innovation typology on its performance: Empirical evidence from Chinese enterprises, Journal of Engineering and Technology Management, 34, 78-98, http://dx.doi.org/10.1016/j.jengtecman.2013.11.001

du Plessis, C., 2012, Towards a regenerative paradigm for the built environment, Building Research \& Information, 40(1), 7-22.

Eisenhardt, K, 1989, Building theories from case research. Academy of Management Review, 14: 532- 550 .

Fellner, J., Lederer, J., Scharff, C. and Laner, D., 2017, Present potentials and limitations of a circular economy with respect to primary raw material demand, Journal of Industrial Ecology, 21 (3), 494-496 Gann, D. 1994, 'Innovation in the construction sector', in M. Dodgson and R. Rothwell (eds), The Handbook of Innovation, Aldershot, UK and Brookfield, US: Edward Elgar.șe? 
Geng, Y., Sarkis, J. and Ulgati, S., 2016, Sustainability, wellbeing, and the circular economy in China and worldwide, Science, March

Gioia, D., Corley, K. and Hamilton, A. 2012. Seeking Qualitative Rigor in Inductive Research: Notes on the Gioia Methodology, Organizational Research Methods 0(0), 1-17.

Green, K., McMeekin, A., Irwin, A., 1994. Technological trajectories and R\&D for environmental innovation in UK firms, Futures 26, 1047-1059.

Gregson, N., Crang, M., Fuller, S. and Holmes, H., 2015, Interrogating the circular economy: the moral economy of resource recovery in the EU, Economy and Society, 44:2, 218-243, DOI: 10.1080/03085147.2015.1013353

Hellstrom, T., 2007, Dimensions of Environmentally Sustainable Innovation: the Structure of EcoInnovation Concepts, Sustainable Developmentsep: 1, 5, 148-159, DOI: 10.1002/sd.309

Helm, D., 2015, Natural Capital: Valuing the Planet, Yale University Press: London

Hofstra, N. and Huisingh, D., 2014, Eco-innovations characterized: a taxonomic classification of relationships between humans and nature, Journal of Cleaner Production, 66, 459-468

Hojnik, J., and Ruzzier, M., 2016, What drives eco-innovation? A review of an emerging literature, Environmental Innovation and Societal Transitions, 19, 31-41, http://dx.doi.org/10.1016/j.eist.2015.09.006

Horbach, J., Rammer, C. and Rennings, K., 2012, Determinants of eco-innovations by type of environmental impact - The role of regulatory push/pull, technology push and market pull, Ecological Economics, 78, 112-122, http://dx.doi.org/10.1016/j.ecolecon.2012.04.005

Horbach, J., 2016, Empirical determinants of eco-innovation in European countries using the community innovation survey, Environmental Innovation and Societal Transitions, 19, 1-14, http://dx.doi.org/10.1016/j.eist.2015.09.005

Huber, J., 2008, Pioneer countries and the global diffusion of environmental innovations: Theses from the viewpoint of ecological modernisation theory, Global Environmental Change, 18 (3), 360-367, http://dx.doi.org/10.1016/j.gloenvcha.2008.03.004

Kemp, R., 1997. Environmental Policy and Technical Change. Edward Elgar, Cheltenham, Brookfield. Kesidou, E., and Demirel, P., 2012, On the drivers of eco-innovations: Empirical evidence from the UK, Research Policy, 41 (5), 862-870, http://dx.doi.org/10.1016/j.respol.2012.01.005

King, N., 2006, Using Interviews in Qualitative Research. In: Cassell, C. and Symon, G. (eds.) Essential guide to qualitative methods in organizational research, Reprint. Sage Publ., London, 1122.

Khanna, M. Deltas, G., Harrington, D.R., 2009, Adoption of Pollution Prevention Techniques: The Role of Management Systems and Regulatory Pressures, Environ Resource Econ, 44, 85-106, DOI 10.1007/s10640-009-9263-y

Mang, P. and Reed, W., 2012, Designing from place: a regenerative framework and methodology, Building Research \& Information, 40 (1), 23-38.

Mickwitz, P., Hyvättinen, H., and Kivimaa, H., 2008, The role of policy instruments in the innovation and diffusion of environmentally friendlier technologies: popular claims versus case study experiences, Journal of Cleaner Production, 16 (1), 162-170, http://dx.doi.org/10.1016/i.jclepro.2007.10.012 
Miozzo, M. and Dewick, P., 2004, Networks and innovation in European construction: benefits from inter-organisational co-operation in a fragmented industry, International Journal of Technology Management, 27, 1. 68-92, https://doi.org/10.1504/IJTM.2004.003882

Miozzo, M. and Dewick, P., 2002, Building competitive advantage: Innovation and corporate governance in European construction, Research Policy, 31, 6. 989-1008

Nam, C.H. and C.B. Tatum, 1988, Major characteristics of constructed producers and resulting limitations of construction technology, Construction Management and Economics, 6, 133-48.

Ness, D.A. and Xing, K., 2017, Toward a resource efficient built environment: a literature review and conceptual model, Journal of Industrial Ecology, 21 (3), 572-592

Ng, F., Harding, J.A., Glass, J., 2016, An eco-approach to optimise efficiency and productivity of a hydraulic excavator, Journal of Cleaner Production, 112 (5), pp. 3966-3976, http://dx.doi.org/10.1016/.j.jclepro.2015.06.110.

Paris, R., Myatt, C. and de Silva, M., 2017, Crossrail project: environmental management during delivery of London's Elizabeth line, Proceedings of the Institution of Civil Engineers,

http://dx.doi.org/10.1680/jcien.17.00021

Peñasco, C., del Río, P., Romero-Jordán, D., 2016, Analysing the Role of International Drivers for Eco-innovators, Journal of International Management, http://dx.doi.org/10.1016/i.intman.2016.09.001. Plimmer, G., (2015), Crossrail earth shipped out to create wildlife reserve, Financial Times, September $11^{\text {th }} 2015$

Popp, D., Hafner, T., Johnstone, N., 2011, Environmental policy vs. public pressure: Innovation and diffusion of alternative bleaching technologies in the pulp industry, Research Policy, 40 (9), pp.12531268, http://dx.doi.org/10.1016/j.respol.2011.05.018

Ramanathan, R., He, Q., Black, A., Ghobadian, A., and Gallear, D., 2016, Environmental regulations, innovation and firm performance: A revisit of the Porter hypothesis, Journal of Cleaner Production, http://dx.doi.org/10.1016/j.jclepro.2016.08.116 .

Rennings, K., 2000, Redefining innovation - eco-innovation research and the contribution from ecological economics, Ecological Economics, 32, 319-332

Rennings, K., Zieglera, A., Ankeleb, K., Hoffmann, E., 2006, The influence of different characteristics of the EU environmental management and auditing scheme on technical environmental innovations and economic performance, Ecological Economics, 57, 45-59, doi:10.1016/j.ecolecon.2005.03.013 Rennings, K., Markewitz, P., Vögele, S., 2012, How clean is clean? Incremental versus radical technological change in coal-fired power plants, Journal of Evolutionary Economics, 23, 331-355, DOI 10.1007/s00191-010-0198-9

Ribeiro, F., and Kruglianskas, I., 2015, Principles of environmental regulatory quality: a synthesis from literature review, Journal of Cleaner Production, 96, 58-76, http://dx.doi.org/10.1016/j.jclepro.2014.03.047

Ridder, H. G., Hoon, C., \& McCandless Baluch, A., 2012, Entering a dialogue: Positioning case study findings towards theory, British Journal of Management, 25(2), 373-387.

Rothwell, R., 1992, Industrial innovation and government environmental regulation: Some lessons from the past, Technovation, 12 (7), 447-458, http://dx.doi.org/10.1016/0166-4972(92)90050-R . 
RSPB 2018a, UK's largest ever coastal wetland restoration project nears completion, available at https://www.rspb.org.uk/about-the-rspb/about-us/media-centre/press-releases/wallasea-island-wildcoast-project-nears-completion/\#FflZJ7b1avd3pUEO.99, last accessed November 2018

RSPB 2018b, Wallasea Island Wild Coast restoration to be completed in 2018, available at https://www.rspb.org.uk/about-the-rspb/about-us/media-centre/press-releases/wallasea-Island-2018restoration-underway/\#uCcT68YXVpRwlpO4.99, last accessed November 2018

Sanni, M., 2018, Drivers of eco-innovation in the manufacturing sector of Nigeria, Technological Forecasting \& Social Change, 131, 303-314, https://doi.org/10.1016/i.techfore.2017.11.007

Tisserant, A., Pauliuk, S., Merciai, S., Schmidt, J., Fry, J., Wood, R., Tukker, A., 2017, Solid Waste and the Circular Economy: A Global Analysis of Waste Treatment and Waste Footprints, Journal of Industrial Ecology, 21 (3), 628-640, DOI: 10.1111/jiec.12562

Triguero, A., Fernández, S., Sáez-Martinez, F.J., 2018, Inbound open innovative strategies and ecoinnovation in the Spanish food and beverage industry, Sustainable Production and Consumption, 15, 49-64, https://doi.org/10.1016/i.spc.2018.04.002

Triguero, A., Moreno-Mondéjar, L., and Davia, M.A., 2013, Drivers of different types of eco-innovation in European SMEs, Ecological Economics, 92, 25-33, http://dx.doi.org/10.1016/j.ecolecon.2013.04.009.

United Nations, 2015, Transforming our world: the 2030 agenda for sustainable development, A/RES/70/1, available at http://www.un.org/ga/search/view doc.asp?symbol=A/RES/70/1\&Lang=E, last accessed August 2017

Van der Ryn, S. and Cowan, S., 2007, Ecological Design, 10th Anniversary, 2nd edition, Island Press, Washington, DC.

Vaughan S., 2011, Elite and Elite-lite Interviewing. Managing our Industrial Legacy. In Alex Franklin, Paul Blyton (eds.) Researching sustainability. A guide to social science methods, practice, and engagement, London: Earthscan, 105-119.

Vergragt, P., Akenji, L., Dewick, P., 2014, Sustainable Production, Consumption, and Livelihoods: Global and Regional Research Perspectives, Journal of Cleaner Production, http://dx.doi.org/10.1016/j.jclepro.2013.09.028, 72, 15. 1-13

Veugelers, R., 2012, Which policy instruments to induce clean innovating?, Research Policy, 41, 1770-1778

Wagner, M., 2008. Empirical influence of environmental management on innovation: evidence from Europe. Ecological Economics 66, 392-402.

Wagner, M. and Llerena, P., 2011, Eco-innovation through integration, regulation and cooperation: comparative insights from case studies in three manufacturing sectors, Industry and Innovation, 18:8, 747-764

Winch, G., 1998, Zephyrs of creative destruction: Understanding the management of innovation in construction, Building Research and Information, Vol. 26, No. 4, pp.268-279

WRAP, 2013, Review of the factors causing waste soil to be sent to landfill, 2007 to 2011, available at

http://www.wrap.org.uk/sites/files/wrap/CIS101301\%20Final\%20Report\%20final\%2017\%20april\%2013.pdf, last accessed July 2017 
Yang. F. and Yang, M., 2015, Analysis on China's eco-innovations: Regulation context, intertemporal change and regional differences, European Journal of Operational Research, 247, 1003-1012, http://dx.doi.org/10.1016/j.ejor.2015.07.029

Yuan, B., Ren, S., Chen, X., 2017, Can environmental regulation promote the coordinated development of economy and environment in China's manufacturing industry? A panel data analysis of 28 subsectors, Journal of Cleaner Production, 149, 11-24

You, D., Zhang, Y. and Yuan, B., 2019, Environmental regulation and firm eco-innovation: Evidence of moderating effects of fiscal decentralization and political competition from listed Chinese industrial companies, Journal of Cleaner Production, 207, 1072-1083, https://doi.org/10.1016/j.jclepro.2018.10.106

Zhao, X. and Sun, B., 2016, The influence of Chinese environmental regulation on corporation innovation and competitiveness, Journal of Cleaner Production, 112, 1528-1536, http://dx.doi.org/10.1016/j.jclepro.2015.05.029 


\section{Appendix: Interview topic guide}

1. Could you tell us please about your role in [this organisation] and your interest/understanding about the issue about the recovery and disposal of spoil?

2. What do you think are the main waste challenges affecting the construction and demolition sector in the UK?

a. Where does the reuse of spoil rank in terms of the main sustainability challenges facing the sector?

3. Are you aware of the regulatory context for waste disposal and recovery in the sector?

a. EU waste framework directive - waste hierarchy

b. The waste (England and Wales) regulations 2011

c. Environmental permitting for waste (Schedule 3 of waste regulation 2011)

4. Before the EU waste framework directive, what routinely happened to spoil? Was there any innovation in the use of spoil? Were you expecting a change in the regulation? Why?

5. Generally speaking, what have been the main changes since the regulatory changes occured? When did these changes happen? What activities were involved? Specifically, can you tell me about changes within your own organisation and changes in the way your organisation worked with others in the supply chain?

6. Generally speaking, which actor(s) has/have mainly driven these changes? Which actor(s) do you think has(ve) the greatest influence on the innovative use of spoil? How can this/these actor(s) stimulate wider change in the industry (i.e. accelerate the diffusion of these innovations)?

7. What factors are hindering these new practices being the norm across the industry? How might these barriers be overcome? Which actor(s) is/are central to driving change? 
Table 1: List of archival material reviewed

\begin{tabular}{|c|c|c|}
\hline Sources & URL & Type \\
\hline EU Landfill Directive 1999 & $\begin{array}{l}\text { https://eur- } \\
\text { lex.europa.eu/LexUriServ/LexUriServ.do?uri=OJ:L:1999:182:0001:0019:EN:PDF }\end{array}$ & EU Council Directive \\
\hline EU Water Framework Directive 2000 & https://eur-lex.europa.eu/legal-content/EN/TXT/?uri=CELEX:32000L0060 & EU Council Directive \\
\hline EU Waste Framework Directive 2008 & http://ec.europa.eu/environment/waste/framework & EU Council Directive \\
\hline $\begin{array}{l}\text { EU Classification, Labelling and Packaging } \\
\text { Regulations } 2008\end{array}$ & http://eur-lex.europa.eu/LexUriServ/LexUriServ.do?uri=COM:2007:0355:FIN:EN:HTML, & EU Regulation \\
\hline UK Environmental Protection Act 1990 & http://www.legislation.gov.uk/ukpga/1990/43/pdfs/ukpga 19900043 en.pdf & UK Government Legislation \\
\hline UK Planning Act 2008 & http://www.legislation.gov.uk/ukpga/2008/29/pdfs/ukpga 20080029 en.pdf & UK Government Legislation \\
\hline UK Town and Country Planning Act 1990 & http://www.legislation.gov.uk/ukpga/1990/8/pdfs/ukpga 19900008 en.pdf & UK Government Legislation \\
\hline UK Hazardous Waste Regulations 2005 & http://www.legislation.gov.uk/uksi/2005/894/pdfs/uksi 20050894 en.pdf & UK Government Regulation \\
\hline $\begin{array}{l}\text { Environmental Permitting (England and Wales) } \\
\text { Regulations } 2007\end{array}$ & http://www.legislation.gov.uk/uksi/2007/3538/contents/made & UK Government Regulation \\
\hline $\begin{array}{l}\text { Environmental Permitting (England and Wales) } \\
\text { Regulations } 2010\end{array}$ & https://www.legislation.gov.uk/ukdsi/2010/9780111491423/contents & UK Government Regulation \\
\hline $\begin{array}{l}\text { Waste (England and Wales) Regulations } 2011 \\
\text { and } 2012\end{array}$ & http://www.legislation.gov.uk/uksi/2011/988/contents/made & UK Government Regulation \\
\hline Landfill Regulations 1996 and 2015 & http://www.legislation.gov.uk/uksi/2005/1640/pdfs/uksi 20051640 en.pdf & UK Government Regulation \\
\hline UK Landfill Tax 1999 & https://www.gov.uk/green-taxes-and-reliefs/landfill-tax & UK Government Guidance \\
\hline UK Aggregates Levy 2002 & https://www.gov.uk/green-taxes-and-reliefs/aggregates-levy & UK Government Guidance \\
\hline $\begin{array}{l}\text { Environmental Permitting Guidance: The waste } \\
\text { framework directive }\end{array}$ & $\begin{array}{l}\text { https://www.gov.uk/government/publications/environmental-permitting-guidance-the-waste- } \\
\text { framework-directive }\end{array}$ & UK Government Guidance \\
\hline $\begin{array}{l}\text { Environmental Permitting Guidance: The Landfill } \\
\text { Directive }\end{array}$ & $\begin{array}{l}\text { https://www.gov.uk/government/publications/environmental-permitting-guidance-the- } \\
\underline{\text { landfill-directive }}\end{array}$ & UK Government Guidance \\
\hline $\begin{array}{l}\text { Guidance on the legal definition of waste and its } \\
\text { application }\end{array}$ & https://www.gov.uk/government/publications/legal-definition-of-waste-guidance & UK Government Guidance \\
\hline Guidance on applying the waste hierarchy & https://www.gov.uk/government/publications/guidance-on-applying-the-waste-hierarchy & UK Government Guidance \\
\hline Guidance on waste recovery plans and permits & https://www.gov.uk/guidance/waste-recovery-plans-and-permits & UK Government Guidance \\
\hline Guidance: Waste environmental permits & https://www.gov.uk/guidance/waste-environmental-permits & UK Government Guidance \\
\hline
\end{tabular}




\begin{tabular}{|c|c|c|}
\hline Sources & URL & Type \\
\hline $\begin{array}{l}\text { CD\&E waste: Halving construction, } \\
\text { demolition and excavation waste to landfill } \\
\text { by } 2012 \text { compared to } 2008\end{array}$ & https://www.greenconstructionboard.org/otherdocs/CD\&E waste from landfill 2011 Report.pdf & Industry Report \\
\hline $\begin{array}{l}\text { Review of the factors causing waste soil to } \\
\text { be sent to landfill } 2007-2011\end{array}$ & $\begin{array}{l}\text { http://www.wrap.org.uk/sites/files/wrap/CIS101- } \\
\text { 301\%20Final\%20Report\%20final\%2017\%20april\%2013.pdf }\end{array}$ & Industry Report \\
\hline $\begin{array}{l}\text { The definition of waste: development } \\
\text { industry code of practice }\end{array}$ & $\begin{array}{l}\text { https://www.claire.co.uk/projects-and-initiatives/dow-cop/28-framework-and-guidance/111-dow- } \\
\text { cop-main-document }\end{array}$ & Industry Report \\
\hline $\begin{array}{l}\text { Guidance for the construction industry on } \\
\text { environmental permitting regime and its } \\
\text { application to construction waste }\end{array}$ & $\begin{array}{l}\text { https://www.ceca.co.uk/wp-content/uploads/legacy-media/300067/ceca-waste-classification-and- } \\
\text { permitting-in-construction-february-2018.pdf }\end{array}$ & $\begin{array}{l}\text { Professional Association } \\
\text { Guidance (CECA) }\end{array}$ \\
\hline What is waste guide (UKCG) & Document no longer available on UK build website & $\begin{array}{l}\text { Professional Association } \\
\text { Guidance (UKCG) }\end{array}$ \\
\hline Aggregates from Inert Waste & https://mineralproducts.org/documents/aggregates quality protocol.pdf & $\begin{array}{l}\text { Environment Agency } \\
\text { Guidance }\end{array}$ \\
\hline $\begin{array}{l}\text { CLAIRE } \\
\text { WRAP } \\
\text { BRE } \\
\text { CECA } \\
\text { BIS } \\
\text { EA } \\
\text { DEFRA } \\
\text { Green Building Council }\end{array}$ & $\begin{array}{l}\text { https://www.claire.co.uk } \\
\text { http://www.wrap.org.uk } \\
\text { https://bregroup.com } \\
\underline{\text { https://www.ceca.co.uk }} \\
\text { https://www.gov.uk/government/organisations/department-for-business-innovation-skills } \\
\underline{\text { https://www.gov.uk/government/organisations/environment-agency }} \\
\text { https://www.gov.uk/government/organisations/department-for-environment-food-rural-affairs } \\
\underline{\text { https://www.ukgbc.org }}\end{array}$ & Industry websites \\
\hline
\end{tabular}




\begin{tabular}{|l|l|l|}
\hline \multicolumn{1}{|c|}{ Sources } & & URL \\
\hline CIWM & $\underline{\text { https://www.ciwm.co.uk }}$ & \\
ICE & $\underline{\text { https://www.ice.org.uk }}$ & Type \\
The Environmentalist & $\underline{\text { http://www.theenvironmentalist.com }}$ & Trade news \\
Planning News & $\underline{\text { https://www.planningresource.co.uk }}$ & \\
Construction News & $\underline{\text { https://www.constructionnews.co.uk }}$ & \\
Infrastructure Intelligence & $\underline{\text { http://www.infrastructure-intelligence.com }}$ & National news \\
\hline BBC & $\underline{\text { http://www.bbc.co.uk }}$ & \\
\hline Guardian & $\underline{\text { http://www.guardian.co.uk }}$ & \\
\hline Financial Times & $\underline{\text { http://www.ft.com }}$ & \\
\hline
\end{tabular}

